\title{
Proses Keperawatan dan Perilaku Caring Dalam Keperawatan
}

\author{
Ftri Rahman Batubara
}

191101103

\begin{abstract}
Abstrak
Proses keperawatan adalah serangkaian tndakan yang sistematis, berurutan, berkelanjutan/bekesinambungan dimulai dari pegumpulan data, menentukan masalah keperawatan, menyusun desain rencana tindakan keperawatan, melaksanakan tindakan dan atau menugaskan orang lain untuk melaksanakan tndakan dan mengevaluasi keberhasilan. Proses keperawatan merupakan metode yang digunakan dalam memberikan asuhan kepada pasien. Sasaran asuan yang diberikan dapat indvidu, kelompok, keluarga, masyarakat,baik sehat maupun sakit. Oleh Karena itu maka masalah yang menjadi perhatian pada asuhan keperawatan adalah sedang terjadi, atau berisik terjadi, maupun masalah yang positif. Area asuhan dapat berupa promotif, kuratif, dan rehabilitatif. Perilaku caring perawat menjadi inti dalam pemberian asuhan keperawatan pada pasien. Perawat sering mendapat kritikan terjadinya perilaku yang masih belum dekat dengan pasien, kurang responsive terhadap permasalahan pasien dan berbagai stikma negative lainnya. Keperawatan dan caring merupakan suatu hal yang tidak dapat dipisahkan. Caring menggambarkan inti dari praktik keperawatan yang bertujuan untuk meningkatkan kepedulian dalam pencapaian pelayanan keperawatan yang lebih baik dan membangun struktur sosial yang lebih baik.
\end{abstract}

Kata Kunci : Proses Keperawatan, Perilaku Caring 
1. Latar Belakang

. Perilaku perawat di tempat pelayanan kesehatan atau rumah sakit dalam menghadapi pasien sangat menentukan bagi pasien untuk mendapatkan pelayanan yang memuaskan. Perawat memberikan pengaruh besar untuk menentukan kualitas pelayanan rumah sakit. Terutama dengan sikap caring yang memperhatikan pasien secara humanistik akan meningkatkan hubungan perawatklien menjadi harmonis dan meningkatkan kepuasan pasien. Rumah sakit memiliki peran yang sangat strategis dalam upaya mempercepat peningkatan derajat kesehatan masyarakat. Paradigma baru pelayanan kesehatan mengharuskan rumah sakit memberikan pelayanan berkualitas sesuai kebutuhan dan keinginan pasien dengan tetap mengacu pada kode etik profesi. Dalam perkembangan teknologi yang pesat dan persaingan yang semakin ketat, maka rumah sakit dituntut untuk terus melakukan peningkatan kualitas pelayanannya

Proses keperawatan adalah aktifitas yang mempunyai maksud yaitu praktik keperawatan yang dilakukan secara sistematik.
Selama melakukan proses keperawatan, perawat menggunakan dasar pengetahuan yang komprehensif untuk mengkaji status kesehatan klien, membuat penilaian yang bijaksana dan mendiagnosa, mengidentifikasi hasil akhir kesehatan klien dan merencanakan, menerapkan dan mengevaluasi tindakan keperawatan yang tepat guna mencapai hasil akhir tersebut. Proses asuhan keperawatan adalah suatu metode yang sistematis untuk mengkaji respons manusia terhadap masalah-masalah kesehatan dan membuat rencana keperawatan yang bertujuan untuk mengatasi masalah-masalah tersebut. Proses asuhan keperawatan adalah suatu metode yang sistematis dan terorganisasi dalam pemberian asuhan keperawatan, yang difokuskan pada reaksi dan respon untuk individu pada suatu kelompok atau perorangan terhadap gangguan kesehatan yang dialami.

Caring secara umum dapat diartikan sebagai suatu kemampuan untuk berdediksi bagi orang lain, pengawasan dengan waspada, perasaan empati pada orang lain dan perasaan cinta atau menyayangi. 
Dalam keperawatan, caring

menggunakan referensi yang

merupakan bagian inti yang penting

terutama dalam praktik keperawatan

dan diyakini berperilaku caring untuk

klien dan bekerja bersama dengan

klien dari berbagai lingkungan

merupakan esensi keperawatan.

Perilaku caring dalam keperawatan sangat diperlukan, tetapi belum semua perawat melayani pasien dengan caring, hal ini dapat dilihat dari perawat yang bekerja diruang perawatan umum menunjukkan bahwa perawat lebih fokus pada pelayanan kebutuhan biologis, dan kurang memperhatikan afektif pasien.

\section{Metode}

Metode yang digunakan dalam kajian ini adalah metode kulaitatif yang bersifat deskriptif mengenai bahaya psikosial dan bagaimana upaya pencegahannya demi kenyamanan dalam bekerja. Metode ini berusaha menjelaskan, mengumpulkan, dan menginterpretasikan data yang dilanjutkan dengan faktor-faktor yang berhubungan dengan situasi dan kondisi yang terjadi. Teknik pengumpulan data yang digunakan oleh penulis adalah teknik studi kepustakaan (Library research)

tersedia baik data dari buku, Ejournal, Google Schoolar, hingga penelitian sebelumnya yang bertema upaya mencegah hazard psikososial, yaitu menelusuri literature yang ada dengan membaca serta menganalisisnya dengan memanfaatkan buku, dan jurnal.

\section{Hasil}

Dari hasil review berbagai sumber di dapatkan hasil bahwa perilaku caring perawat baik dikarenakan semua responden sudah berpendidikan tinggi, Peran pendidikan dalam membangun caring perawat sangat penting. Pengetahuan seseorang juga dipengaruhi oleh tingkat pendidikannya Semakin luas pengetahuan perawat, maka berhubungan dengan tingkat caring yang semakin tinggi dan berdampak pada penerimaan tanggung jawab dalam menyelesaikan tanggung jawabnya dengan baik.

Proses keperawatan memberikan panduan sistematis atau metode untuk membantu peserta didik atau perawat mengembangkan pola berfikir yang 
mengarah pada penelitian klinis yang tepat. Penyusunan proses keperawatan dilakukan sebagai alat pengajaran untuk membantu peserta didik belajar keterampilan berfikir kritis untuk praktek keperawatan. Proses keperawatan mengarah peserta didik dan praktisi dalam menerapkan pengetahuan yang mendasar ke dalam praktik. Proses keperawatan digunakan untuk membantu perawat melakukan praktik keperawatan secara sistematis dalam memecahkan masalah keperawatan. Dengan metode ini, perawat dapat mendemonstrasikan tanggung gugat pada klien, sehingga kualitas praktek keperawatan dapat ditingkatkan. Asuhan keperawatan pada klien, keluarga dan komunitas, serta merupakan metode yang efisien dalam membuat keputusan klinik, serta pemecahan masalah baik aktual maupun potensial dalam mempertahankan kesehatan.

Proses keperawatan adalah aktifitas yang mempunyai maksud yaitu praktik keperawatan yang dilakukan secara sistematik. Selama melakukan proses keperawatan, perawat menggunakan dasar pengetahuan yang komprehensif untuk mengkaji status kesehatan klien, membuat penilaian yang bijaksana dan mendiagnosa, mengidentifikasi hasil akhir kesehatan klien dan merencanakan, menerapkan dan mengevaluasi tindakan keperawatan yang tepat guna mencapai hasil akhir tersebut. Proses asuhan keperawatan adalah suatu metode yang sistematis untuk mengkaji respons manusia terhadap masalah-masalah kesehatan dan membuat rencana keperawatan yang bertujuan untuk mengatasi masalah-masalah tersebut. Proses asuhan keperawatan adalah suatu metode yang sistematis dan terorganisasi dalam pemberian asuhan keperawatan, yang difokuskan pada reaksi dan respon untuk individu pada suatu kelompok atau perorangan terhadap gangguan kesehatan yang dialami, dengan tetap mengaplikasikan peilaku caring.

\section{Pembahasan}

Keperawatan merupakan profesi unik yang memiliki fokus utama caring, yaitu bagaimana memberikan dan mengelola asuhan yang dibutuhkan pasien. Hal ini menjadikan perawat memiliki 
peran baik pemberi asuhan sebagai kemampuan klinis dan juga koordinator sebagai komponen manajerial. Peran perawat sebagai pemberi asuhan merupakan komponen penting yang esensial dalam sistem pemberian pelayanan kesehatan. Kemampuan dan keterampilan perawat yang kuat dalam kepemimpinan dan administratif sangat penting bagi pasien dan keselamatannya serta sistem layanan dan aksesnya. Mutu asuhan yang unggul dapat memenuhi kebutuhan masyarakat terhadap kesehatan. Tuntutan tersebut membuat perawat perlu dipersiapkan dengan baik untuk membuat dan memelopori strategi perubahan dan mengelola secara efektif koordinasi dan integrasi dari tim interdisipliner, kebutuhan masyarakat, dan sistem asuhan yang berkelanjutan. Proses keperawatan membantu perawat mendapatkan luaran, mengukur kualitas pelaksanaan asuhan keperawatan dan memudahkan perawat untuk melakukan praktik klinis keperawatan khususnya bagi perawat pemula. Proses keperawatan terdiri dari lima tahapan, yaitu pengkajian, diagnosis, perencanaan, implementasi, dan evaluasi.

Proses

keperawatan

merupakan gambaran dari hubungan antara pasien dan perawat, identitas dan peran profesionalitas perawat, dan pengembangan pengetahuan perawat. Hubungan antara pasien dan perawat merupakan interaksi timbal balik dimana respon pasien dan perawat saling memengaruhi dan terus berkembang sejalan dengan perubahan respon antara pasien dan perawat. Salah satu fungsi profesionalitas perawat adalah menemukan kebutuhan pasien yang tidak terpenuhi dan kemudian memberikan bantuan untuk memenuhi kebutuhan tersebut. Proses keperawatan memfasilitasi perawat untuk berkembang sebagai seorang pemikir yang logis untuk menghasilkan peningkatan respon dan perilaku pasien dalam pemenuhan kebutuhannya serta pentingnya partisipasi pasien dalam keseluruhan proses. Proses keperawatan memiliki beberapa sifat yang membedakannya dengan metode lain. Sifat pertama adalah dinamis, artinya setiap langkap dalam proses keperawatan dapat 
kita perbarui jika situasi yang kita hadapi berubah. Sifat kedua adalah siklus, artinya proses keperawatan berjalan menurut alur siklus tertentu : pengkajian, penetapan diagnosis, perencanaan, implementasi dan evaluasi. Sifat ketiga adalah saling ketergantungan, artinya masingmasing tahapan pada proses keperawatan saling bergantung satu sama lain. Sifat terakhir adalah fleksibilitas, artinya urutan pelaksanaan proses keperawatan dapat berubah sewaktu-waktu, sesuai dengan situasi dan kondisi klien.

\section{Ada 6 Manfaat Proses}

Keperawatan, yakni :

- Meningkatkan layanan mutu keperawatan

Proses keperawatan merupakan metode sistematis yang menjadi panduan bagi perawat dalam memberikan asuhan keperawatan. Jika setiap perawat dapat menggunakan proses keperawatan dengan benar dan tepat, ini akan meningkatkan mutu layanan keperawatan. Melalui proses keperawatan, setiap perawat bertindak secara profesional sesuai dengan lingkup wewenang dan tanggung jawabnya.
- Meningkatkan citra profesi keperawatan

Melalui penerapan proses keperawatan, mutu layanan keperawatan dapat di tingkatkan. Ini merupakan salah satu upaya promosi yang paling efektif, tepat, dan langsung untuk mengubah persepsi masyarakat dan profesi lain tentang profesi keperawatan. Pencitraan negatif yang dituduhkan terhadap profesi keperawatan salah satunya disebabkan oleh perilaku perawat diposisikan bukan sebagai suatu profesi yang profesional, melainkan sebagai pembantu profesi lain, yakni kedokteran. Ini merupakan penyebab lain dari citra negatif keperawatan. Hingga saat ini, pencitraan semacam itu masih sering terlontar, terutama dari profesi non-keperawatan.

- Mengambarkan otonomi dan tanggung jawab perawat

- Proses keperawatan memberi arah bagi perawat dalam melaksanakan asuhan keperawatan, mulai dari pengkajian sampai evaluasi. Salah satu komponen proses keperawatan yang penting adalah perencanaan tindakan keperawatan. Pada tahap ini, perawat memiliki otonomi yang penuh dalam merencanakan 
tindakan keperawatan bagi klien.

Itu berarti perawat melaksanakan intervensi keperawatan kepada klien bukan didasarkan atas instruksi dari profesi lain. Selain itu, melalui proses keperawatan, profesi lain akan mengetahui apa yang akan menjadi kewenangan dan tanggung jawab perawat. Lebih lanjut, tahap evaluasi dari proses keperawatan merupakan suatu mekanisme kontrol yang mencerminkan tanggung jawab perawat terhadap asuhan keperawatan yang diberikan kepada klien.

- Mengembangkan keterampilan teknis dan intelektual perawat

Dalam memberikan asuhan keperawatan kepada klien, perawat sebaiknya tidak terjebak pada kegiatan yang sifatnya rutinitas. Dikhawatirkan ini akan menghambat perkembangan kemampuan intelektual dan teknis perawat sebab perawat bekerja ibarat robot. Seperti kita ketahui, proses keperawatan merupakan kerangka berfikir secara kritis, logis, dan sistematis, serta kerangka bertindak secara etis dan rasional kepada klien. Penerapan proses keperawatan yang baik dan benar akan mengembangkan kemampuan tersebut.

- Meningkatkan rasa solidaritas dan rasa kesatuan perawat

Proses keperawatan dilakukan secara berkesinambungan dan komprehensif. Proses keperawatan dapat berfungsi sebagai media komunikasi antar-perawat sehingga akan tercipta rasa kebersamaan. Manfaat yang lebih besar adalah terbina dan terpeliharanya kesatuan dan persatuan diantara perawat.

- Menghasilkan praktik keperawatan yang profesional

Penerapan proses keperawatan didasarkan pada metode ilmiah, bukan pada intuisi semata. Penerapan proses keperawatan menunjukkan ciri-ciri profesionalisme, diantaranya mengutamakan kepentingan klien (client oriented), menggunakan pengetahuan ilmiah, serta menunjukkan tanggung jawab dan tanggung gugat dalam melaksanakan praktik keperawatan. Jika perawat bertindak dan berprilaku secara profesional, masyarakat dan profesi lain akan menilai dan mengakui perawat sebagai tenaga professional 
Watson pada tahun 2009 menempatkan caring sebagai dasar dan sentral dalam praktek keperawatan. Caring memberikan kemampuan pada perawat untuk memahami dan menolong klien. Seorang perawat harus memiliki kesadaran tentang asuhan keperawatan, dalam memberikan bantuan bagi klien dalam mencapai atau mempertahankan kesehatan atau mencapai kematian dengan damai. Watson pada tahun 2012 dalam Theory of Human Care mengungkapkan bahwa ada sepuluh carative factor yang dapat mencerminkan perilaku caring dari seorang perawat. Sepuluh faktor tersebut adalah membentuk sistem nilai humanistik-altruistik, menanamkan keyakinan dan harapan, mengembangkan sensitivitas untuk diri sendiri dan orang lain, membina hubungan saling percaya dan saling membantu, meningkatkan dan menerima ekspresi perasaan positif dan negatif, menggunakan metode pemecahan masalah yang sistematis dalam pengambil an keputusan, meningkatkan proses belajar mengajar interpersonal, menyediakan lingkungan yang mendukung, melindungi, dan atau memperbaiki mental, sosiokultural dan spiritual, membantu dalam pemenuhan kebutuhan dasar manusia, mengembangkan faktor kekuatan eksistensial fenomenologis. Swanson pada tahun 199T mengilustrasikan perilaku caring dalam lima proses caring, masing-masing bagiannya mempunyai sifat yang berbeda. Knowing berarti perawat yang memahami peristiwa yang dialami pasien dan mampu menciptakan lingkungan yang aman dan bernilai positif bagi pasien, Being with berarti menghadirkan emosi saat bersama pasien, Doing for berarti melakukan pelayanan keperawatan untuk membantu pasien atau mendukung pasien untuk melakukan perawatan mandiri. Enabling berarti membantu pasien dan menfasilitasi pasien agar dapat merawat dirinya sendiri. Enabling believe bererti mempertahankan kepercayaan yang merupakan fondasi mengenali arti suatu kejadian bagi pasien. Berdasarkan 5 proses caring tersebut tercermin sebuah gambaran yang utuh tentan kemampuan kognitif, afektif, dan psikomotor yang menjadi kompetensi dasar yang harus dimiliki seorang perawat. 
Tingkat kepuasan pasien

dalam menerima suatu pelayanan, tentu tidak sama, ada beberapa faktor yang mungkin mempengaruhinya. Faktor-faktor yang mempengaruhi kepuasan pengguna jasa pelayanan kesehatan yaitu, Pemahaman pengguna jasa tentang jenis pelayanan yang akan diterimanya. Dalam hal ini komunikasi memegang peranan yang penting karena pelayanan kesehatan adalah high personel contact, Empati / caring (sikap peduli) yang ditunjukkan oleh petugas kesehatan, Biaya (cost), Penampilan fisik (kerapian) petugas, kondisi kebersihan dan kenyamanan ruangan (tangibility, Jaminan keamanan yang ditunjukkan oleh petugas kesehatan (assurance). Ketepatan jadwal pemeriksaan dan kunjungan dokter juga termasuk pada faktor ini, Keandalan dan keterampilan (reliability) petugas kesehatan dalam memberikan perawatan, Kecepatan petugas memberikan tanggapan terhadap keluhan pasien (responsiveness).

\section{Penutup}

Proses keperawatan adalah aktifitas yang mempunyai maksud yaitu praktik keperawatan yang dilakukan secara sistematik. Selama melakukan proses keperawatan, perawat menggunakan dasar pengetahuan yang komprehensif untuk mengkaji status kesehatan klien, membuat penilaian yang bijaksana dan mendiagnosa, mengidentifikasi hasil akhir kesehatan klien dan merencanakan, menerapkan dan mengevaluasi tindakan keperawatan yang tepat guna mencapai hasil akhir tersebut. Dengan tetap memperhatikan komponen dalam proses keperawatan, yakni Tahap Pengkajian, Tahap Diagnosa Keperawatan, Tahap Perencanaan, Tahap Pelaksanaan, dan Tahap Evaluasi. Selain itu, perilaku Caring harus selalu dilakukan dalam proses keperawatan karena Watson pada tahun 2009 menempatkan caring sebagai dasar dan sentral dalam praktek keperawatan. 


\section{Referensi}

A.A. Komp. Ngurah Darmawan.

2015. Hubungan Perilaku Caring Perawat Terhadap Tingkat Kepuasan Pasien Rawat Inap di RSUD Klugkung. Jurnal Dunia Kesehatan, 5(1).

Cecep S.F., Richa N., Indra K. 2019. Perilaku Caring Perawat Berdasarkan Teori Jean Watson di Ruang Rawat Inap. Jurnal Kesehatan Vokasional, 4(1).

Dheni K., Novita E. D., Srimiyati. 2020. Aplikasi Standar Proses

Keperawatan: Diagnosis, Outcome, dan Intervensi Pada Asuhan Keperawatan.Jurnal Keperawatan Silampari, 3 (2) 739-751.

Diah Fitri Purwaningsih. 2018. Perilaku Caring Perawat Pelaksana di Ruang Rawat Inap. Jurnal Ilmiah Kesehatan, 1(1).

Fitra Yeni. 2014. Pengaruh Pelatihan Proses Keperawatan Terhadap Dokumentasi Asuhan Keperawatan di Puskesmas Kabupaten Agam Provinsi Sumatera Barat. Ners Jurnal Keperawatan, 10(1) 21-27.
Hanna G. K., Sefty R., Rivelino S. H. 2016. Hubungan Tingkat Pendidikan dan Lamanya Kerja dengan Kineja Perawat di Rumah Sakit Umum Kabupate Sorong. EJournal Keperawatan, 4(1).

Mohammad Asa'ad Efendy, Retno Purwandari. 2012. Perbedaan Tingkat Kualitas Dokumentasi Proses Keperawatan Sebelum dan Sesudah Penerapan NANDA-I, NIC, dan NOC. Jurnal Keperawatan Soedirman, 07(2).

Rohmah Nikmatur, dan Walid Siful. 2019. Proses Keperawatan Berbasis KKNI. Malang: Edulitera.

Selvyyanny Tedjomuljo, Efy A. 2016. Tingkat Pengtahuan Mahasiswa Keperawatan Tentang Kode Etik Profesi dan Caring. Junal Keperawatan Indonesia, 19(2) hal 129-136.

Simamora, R. H. (2019). Development of Guidelines for Applying appropriate Patient Identification to Achieve Patient Safety Goal INC2019 12th International Nursing Conference. 2019.10455 - 455 (1 pages) 
UCI(KEPA) : I410-ECN-0101-

2019-512-001224337

Simamora. R. H. (2008) The correlation of ward chief's giving direction and command and the performance of on-duty nurses at Jember dr. Subandi general hospital inpatient wards. jurnal Administrasi dan Kebijakan
Kesehatan,

(https://fkm.unair.ac.id/jurnal-

$\underline{\text { administr) }}$

Tiara, Arena Lestari. 2013.

Perilaku Caring Perawat Dalam

Meningkatkan Kepuasan Pasien

Rawat Inap. Jurnal Keperawatan, 9(2). 